\title{
Цитационные конструкции в живой японской речи: грамматика и прагматика
}

Подлесская Вера Исааковна, Российский государственный гуманитарный университет (Москва); vi_podlesskaya@il-rggu.ru Ермишина Екатерина Сергеевна, Российский государственный гуманитарный университет (Москва); kyermishina@mail.ru

Исследуется грамматика и прагматика японских конструкций с цитативным (квотативным) показателем to в текстах личных блогов. В работе ставятся две взаимосвязанные цели - (а) описать актуальное употребление квотативов в неформальной электронной коммуникации последнего времени; и (б) поместить данные японского языка в контекст современной дискуссии о противопоставлении прямой и косвенной речи. Показано, что японский язык представляет особый интерес для изучения межъязыкового варьирования цитационных конструкций. Во-первых, в японском языке нет типичных для языков «среднеевропейского стандарта» индексальных выражений: отсутствует личное согласование, личные местоимения 1 и 2 л. употребляются редко; поэтому можно опираться лишь на более периферийные индексальные выражения - бенефактивы, формы вежливости, так называемые заключительные прагматические частицы. Но и эти необязательные индексальные выражения могут давать противоречивые сигналы внутри одного высказывания: одни могут ориентироваться на внешнего нарратора (что типично для прагматически косвенной речи), а другие - на внутреннего говорящего (что типично для прагматически прямой речи). Во-вторых, независимо от того, имеются ли индексальные выражения в составе цитаты и каковы они, цитата вводится квотативным маркером $t o$ в статусе комплементайзера. Это в корне отличает японский язык от языков «среднеевропейского стандарта», где комплементайзером обычно вводятся лишь цитаты в формате косвенной речи, синтаксически являющиеся вложенными клаузами. В-третьих, прагматически прямые цитаты далеко не всегда обрамляются кавычками, особенно в неформальном электронном дискурсе. Таким образом, для японского языка более плодотворным оказывается многофакторный анализ цитации, позволяющий учитывать все многообразие исследуемой зоны и выделять лингвоспецифические кластеры значений разноуровневых параметров.

Ключевые слова: квотатив, цитационные конструкции, прямая речь, косвенная речь, японский язык

\section{QUOTATIVES IN INFORMAL JAPANESE DISCOURSE: GRAMMAR AND PRAGMATICS}

Vera I. Podlesskaya, Russian State University for the Humanities (Moscow); vi_podlesskaya@il-rggu.ru Ekaterina S. Ermishina, Russian State University for the Humanities (Moscow); kyermishina@mail.ru

Based on the data from Japanese personal blogs the paper addresses grammar and pragmatics of the Japanese constructions with the quotative marker to. The aim is twofold: (a) to describe the actual use of quotatives in informal electronic discourse; and (b) to put the Japanese data in the context of the current discussion about the nature of the direct/indirect speech opposition. Japanese is shown to be an intriguing case when it comes to distinguishing direct and indirect reports. First, it lacks standard indexicals typical for languages known as "standard average European", e.g. there is no personal agreement, first and second personal pronouns are extremely rare, hence, one can rely only on optional indexicals, like benefactives, honorifics or the so called final pragmatic particles. Furthermore, even these optional indexicals may operate controversially within one and the same utterance - some being oriented towards the external narrator (which is typical for pragmatically indirect reports) and other being oriented towards the internal speaker (which is typical for pragmatically direct reports). Second, whatever type of indexicals is used, if at all, the report is marked by the quotative marker (complementizer) to. This also distinguishes Japanese from standard average European languages where complementizers normally introduce only pragmatically indirect reports which constitute an embedded clause. Third, the quotation marks (kagi) are optional for pragmatically direct reports, especially in informal electronic discourse. The kind of data we present supports the approach to reported speech that doesn't favor either/or decisions, but rather is based on multifactorial analysis that considers the whole range of possible parameters and isolates their observed language-specific clusters.

Keywords: quotative, reported speech, direct speech, indirect speech, Japanese 


\section{1. Постановка вопроса}

Данная работа посвящена конструкциям с цитационным (в другой терминологии - квотативным) союзом to - одному из основных способов передачи чужой речи (мысли) в современном японском языке. Мы ставим две смежные задачи: дескриптивную - описать употребление цитационных конструкций в реальном узусе, и типологическую - поместить обнаруженные нами данные в контекст дискуссии о возможных параметрах межъязыкового сравнения цитационных конструкций.

Конструкциям передачи чужой речи посвящена большая литература; в центре теоретических и типологических исследований этого явления - вопрос о разграничении прямой и косвенной цитации. Лавинообразное расширение исследуемого круга языков продемонстрировало, что наблюдаемые стратегии цитирования обнаруживают значительную вариативность, которую трудно свести к бинарному противопоставлению прямой и косвенной речи. В частности, далеко не универсален типичный для языков «среднеевропейского стандарта» такой паттерн прямой речи, при котором между авторской ремаркой и цитатой отсутствует подчинительная связь, а дейктические выражения «индексально не согласованы»: дейксис цитаты ориентирован на внутреннего (цитируемого) говорящего, а дейксис авторской ремарки на внешнего (цитирующего) говорящего, или нарратора, сp. [Evans 2013], [Güldemann 2008], [Güldemann, von Roncador (eds.) 2002], [Spronck, Nikitina 2019] и др.

Японский язык - удобный полигон для изучения межъязыковой вариативности цитации, поскольку демонстрирует отклонение от «среднеевропейского стандарта» по крайней мере в двух отношениях. Во-первых, в японских цитационных конструкциях прямая цитата, как и косвенная, вводится цитационным союзом (комплементайзером) to, и, таким образом, прямая цитата оказывается гораздо теснее синтаксически связана с авторской ремаркой, чем прямая цитата в языках типа русского или английского. Во-вторых, в японском языке нет глагольной категории лица, плюс сильно развит эллипсис, т. е. локуторы и ранее упоминавшееся референты чаще опускаются, чем заменяются личными или анафорическими местоимениями. Таким образом, в цитационной конструкции мало дейктических (индексальных) единиц, которые бы однозначно указывали, на кого ориентирован дейксис цитаты и авторской ремарки на нарратора или на внутреннего говорящего. Этот дефицит лишь частично восполняется другими, менее «массовыми» типами индексальных выражений: этикетными формами и конструкциями, особыми глагольными формами, ориентированными на «социальный дейксис» - формами вежливости по отношению к собеседнику, формами вежливости по отношению к субъекту описываемого действия, бенефактивами, императивами и рядом других, ср. [Алпатов, Аркадьев, Подлесская 2008, 2: 319-325], [Coulmas 1985], [Iwasaki 2013: 219—236], [Kuno 1988], [Okamoto, Ono 2008], [Oshima 2006], [Saito 2018] и др.

В монографическом исследовании японской грамматики [Iwasaki 2013: 220] приводятся следующие два примера, демонстрирующие прототипический формат цитационной конструкции в японском языке. Нарратор (внешний говорящий, в тексте не эксплицирован) сообщает внешнему адресату (в тексте не эксплицирован) о произошедшем речевом событии, а именно, о том, что Таро (внутренний говорящий, подлежащее авторской ремарки) сказал девушке по имени Митико (внутренний адресат, косвенное дополнение авторской ремарки и личное местоимение kimi 'ты' в функции посессивного атрибута в цитате), что он хочет увидеться с сестрой этой Митико по имени Маки (косвенное дополнение в цитате): ${ }^{1}$

(1) taroo wa michiko ni kimi no imooto san ni zehi

Tаро тOP Митико DAT ты GEN младшая.сестра HON DAT непременно

a-ita-i naa to it-ta

встретиться-DSD-PRS PRT QUOT сказать-PAST

'Таро сказал Митико: «[Я] непременно хочу увидеть твою сестру!»'

(2) taroo wa michiko ni maki ni a-ita-i to it-ta

Tаро TOP Митико DAT Маки DAT встретиться-DSD-PRS QUOT сказать-PST

'Таро сказал Митико, что [он] хочет увидеть [ее сестру] Маки.'

Согласно [Iwasaki 2013: 220], в примере (1) речевое событие передано в формате прямой речи, в примере (2) - в формате косвенной речи. Как видим, авторская ремарка в обоих случаях оформлена идентично. По общим правилам порядка слов в японском языке как в языке левого ветвления вершинный предикат авторской ремарки - глагол речи - помещен в крайнюю правую позицию. Подлежащее (внутренний говорящий), косвенное дополнение (внутренний адресат) и сентенциальное дополнение

${ }^{1}$ Все иллюстративные примеры в работе - как взятые из нашего рабочего массива, так и заимствованные из литературы - мы снабжаем собственным переводом и глоссингом в формате, разработанном в [Алпатов, Аркадьев, Подлесская 2008]. Список сокращений приведен в конце работы. 
(сама цитата) могли бы располагаться в любом порядке в зависимости от информационной структуры высказывания. В данном случае в обоих вариантах выбран порядок, при котором топикализованное подлежащее расположено в крайней левой позиции, за ним дополнение, и далее - цитата. В обоих случаях цитата вводится цитационным союзом (комплементайзером) to, распложенным на правой границе цитаты. Ни в (1), ни в (2) не использованы кавычки: в японском языке особые угловые кавычки «каги» используются при прямой цитате часто, но не обязательно, см. [Maynard 1998], и таким образом, наличие кавычек может, в общем случае, являться диагностическим контекстом для дифференциации прямой и косвенной речи, а их отсутствие - нет. Что же отличает (1) от (2)?

Во-первых, способ обозначения третьего лица, упоминаемого в цитате. В (1) это лицо обозначено как kimi no imooto san 'твоя младшая сестра'. Это выражение дейктически маркировано: (i) в нем есть редкая для японского языка отсылка к адресату ('твоя’), и (ii) в его составе есть этикетная частица san (по-русски весьма условно ее переводят как 'госпожа/господин'), которая при присоединении к термину родства демонстрирует вежливость к родственникам уважаемого лица, прежде всего - адресата. В (2), напротив, это лицо названо дейктически нейтрально, по имени - Маки.

Во-вторых, в (1) в составе цитаты имеется дейктически маркированное наречие zehi 'непременно', которое выражает оценку с позиции внутреннего, а не внешнего говорящего. В (2) это наречие отсутствует.

В-третьих, в (1) после глагола в форме дезидератива (желательного наклонения) следует частица $n a(a)$ - одна из так называемых заключительных модально-экспрессивных частиц, характерных для диалогического режима речи, см. [Алпатов, Аркадьев, Подлесская 2008, 1: 462—463], [Прасол 1999]. Эти частицы являются типичным представителем «явлений главного предложения» (main clause phenomena) - или, согласно важному уточнению, сделанному Е. В. Падучевой, «предложения, которому соответствует отдельный речевой акт» [Падучева 1996: 229]. С грамматической точки зрения конструкции, в состав которых входят явления главного предложения, обладают свойством синтаксической неподчинимости (ср. также близкий термин "root phenomena" в [Lobke et al. (eds.) 2012] и обширную библиографию там же). К таким явлениям относятся средства выражения субъективной модальности, экспрессивные диалогические элементы, реактивные реплики и проч. Частица $n a(a)$ выполняет в (1) две функции - функцию запроса реакции на высказывание (она особенно характерна для варианта с нефонологическим эмфатическим удлинением гласного, который представлен в данном примере) и функцию смягчения категоричности персонального желания, которое выражено дезидеративом. Считается, что форма дезидератива на -tai, если она не дополнена показателем вежливости к собеседнику (адрессивной связкой $d e s u)$, по этикетным нормам неуместна в диалогическом режиме, и в отсутствие адрессивной связки должна быть дополнена какой-либо из заключительных частиц. Так, в авторитетном грамматическом словаре [Makino, Tsutsui 2009: 479] высказывание, в котором за формой дезидератива на -tai непосредственно следует цитационный союз и далее - авторская ремарка, квалифицируются как косвенная речь (поскольку оригинальное высказывание не могло иметь такого вида в реальном диалоге, следующем этикетным нормам). И именно такой паттерн предъявлен в примере (2).

Эти модельные примеры демонстрируют, что мы имеем дело с языком, в котором прямой и косвенный формат цитирования далеко не всегда разграничены грамматически, а дейктические противопоставления часто нейтрализованы. Мы видим свою задачу в том, чтобы, проанализировав реальный узус, постараться понять, как устроена и как функционирует цитация в языке такого рода.

Материалом для данного исследования послужили цитационные конструкции в текстах электронных дневников (блогов) на бытовые темы платформы www.ameba.jp. Этот тип письменного дискурса был выбран нами потому, что он обладает высоким уровнем спонтанности и неформальности, сближающими его с устной бытовой речью; иначе говоря, мы имеем дело с текстами письменными по модусу, но разговорными по стилю. Мы проанализировали шесть блогов (трое авторов - мужчины, трое - женщины) общим объемом 29537 знаков; методом сплошной выборки было зафиксировано 209 экземпляров интересующей нас конструкции — они и составили эмпирическую базу исследования.

Статья построена следующим образом. В разделе 2 мы обсудим структуру японских цитационных конструкций — в общем случае, единую для прямого и косвенного формата цитации - и постараемся показать, что в исследуемых нами типах текстов обнаруживаются такие способы оформления цитации, которым не всегда уделяется должное внимание в японистической литературе, ориентированной обычно на более кодифицированные жанры дискурса. Раздел 3 посвящен индексальным выражениям в составе цитационных конструкций, засвидетельствованных в нашем материале. Мы продемонстрируем набор средств, которые обеспечивают согласование или, наоборот, рассогласование дейктической перспективы цитаты и авторской ремарки. В заключительном разделе 4 мы попробуем извлечь типологические уроки и оценить место наших дескриптивных результатов в общей панораме средств передачи чужой речи. 


\section{2. Структура цитационных конструкций}

\section{1. Прототипические случаи цитации}

2.1.1. В обследованном нами массиве текстов цитационные конструкции, следующие прототипическому паттерну, проиллюстрированному выше в (1) - (2), составляют примерно половину зарегистрированных случаев цитации. Этот прототипический паттерн схематически можно изобразить следующим образом:

\section{Схема 1.}

$\left(\mathrm{NP}_{1}\right.$ wa/ga $)\left(\mathrm{NP}_{2}\right.$ ni) $\mathrm{S}$ to $\mathrm{V}$

В этой схеме $\mathrm{S}$ - клаузальная составляющая, которая соответствует цитате, она оформлена цитационным союзом to (или его разговорным вариантом tte); $\mathrm{V}$ - вершина матричной клаузы/авторской ремарки, т. е. глагол речи, мысли, реже - чувства и некоторых других типов. Именные группы $\mathrm{NP}_{1}$ и $\mathrm{NP}_{2}$ вводят внутреннего говорящего (топик/подлежащее) и адресата (косвенное дополнение), они могут располагаться как до, так и после цитаты, и они опциональны в соответствии с общими правилами японского эллипсиса: отсылка к локуторам может осуществляться другими именными группами в составе конструкции, именными группами за пределами конструкции в ближнем контексте, или локуторы идентифицируются на экстралингвистических основаниях. Так, в примере (3) ниже внутренний адресат не эксплицирован, хотя и цитата, и авторская ремарка описывают связанные с ним действия и состояния, к нему отсылают квантификатор futari de ‘вдвоем' и глагольная форма гортатива (пригласительного наклонения); при этом внутренний говорящий в (3) эксплицирован - обозначен личным местоимением watashi 'я' (это пример самоцитации, т. е. внешний говорящий, нарратор, совпадает с внутренним). В примере (4), наоборот, в авторской ремарке имеются многократные отсылки к действиям внутреннего говорящего и к его жене, но сам он не назван, а внутренний адресат обозначен личным местоимением omae 'ты' в составе цитаты и существительным yatsu 'парень' в составе авторской ремарки. Существенно однако, что yatsu не фигурирует как актант вершинного глагола авторской ремарки 'поговорить', появляясь в двух других позициях - актанта глагола furachisuru 'негодничать, изменять с кем-либо' и атрибута существительного tokoro 'место (нахождения/проживания)' :

(3) $1.1 .16^{2}$

Sono yasashisa ni gutto ki-ta watashi wa

это доброта DAT всплеск.эмоций наступить-РST я TOP

「wanruumu manshon ja-na-kutte futari de heya o kari-te,

одна.комната жилье COP.TOP-NEG-CNV вдвоем INS комната АCC снять-CNV

issho-ni sum-oo yo」 to teian-shi-mash-ita

вместе-ADV жить-HOR PRT QUOT предложение-VRB-ADR-PST

'Я, глубоко тронутая этой [его] добротой, предложила [ему]: «Не нужно снимать [отдельную] однокомнатную квартиру, давай вдвоем снимем комнату и будем жить вместе»’

(4) 4.1 .77

Demo tsuma ga yatsu to furachi-shi-te i-ta

но жена NOM этот.парень с негодничать-VRB-CNV AUX.PRG-PST

koto ga waka-tta ijoo, yatsu no tokoro ni i-tte

NML NOM понимать-PST когда этот.парень GEN место DAT идти-CNV

$\lceil\text { omae, ittai dooyuu tsumori da! }\rfloor^{3} \quad$ to

ты вообще какой цель COP.PRS QUOT

hanashi o shi-te ki-ma-su.

разговор АCC делать-CNV AUX.DIR-ADR-PRS

'Но когда [он] понял, что [ему] жена с тем парнем изменяет, то [он] пошел к тому парню и поговорил: «Ты, вообще, что себе думаешь?!»'

\footnotetext{
${ }^{2}$ Каждый пример из нашего рабочего массива снабжен индексом, состоящим из номера блога, номера поста внутри блога и номера строки внутри поста.

${ }^{3}$ Парными значками「」 переданы японские угловые кавычки «каги». В строке транслитератции они проставлены в тех местах, которые соответствуют местам в оригинальной графике. Если японская цитата построена как прямая, то в русском переводе в соответствии с правилами русской пунктуации цитата обрамляется стандартными кавычками, даже если в японском источнике кавычек-каги не было.
} 
2.1.2. В тех случаях, где в авторской ремарке есть подлежащее-говорящий, оно, как правило, предшествует цитате; в нашем массиве обнаруживаются лишь единичные случаи, типа (5), где подлежащееговорящий расположено между цитатой и глаголом речи:

(5) 3.2 .81

Nanimo shi-na-kute $i-i \quad$ yo to kare wa it-te kure-ru kedo, ничего делать-NEG-CNV хороший-PRS PRT QUOT он TOP сказаTь-CNV AUX.BEN-PRS но '«Можно ничего не делать», - сказал он [мне], однако...'

Этот результат представляет интерес с типологической точки зрения, поскольку считается, что в левоветвящихся языках тяжелые составляющие должны предшествовать легким [Hawkins 1994], т. е. примеры типа (5) должны были бы быть «мейнстримом», но этого не происходит. Можно предположить, что при цитации в разговорном дискурсе в общее правило упорядочивания составляющих по весу вмешиваются два других фактора. Во-первых, в большинстве зарегистрированных нами случаев подлежащее топикализовано, о чем свидетельствует грамматический маркер топика $w a$. Как показывает пример (5), это не обязательно приводит к тому, что подлежащее выдвигается влево, но, возможно, при прочих равных условиях способствует такому выдвижению (о взаимодействии фактора информационной структуры и фактора веса составляющей см., в частности, [Hawkins 1994: 339-341]). Во-вторых, как будет показано в следующей главе, в большинстве зарегистрированных нами примеров цитата имеет дейктические симптомы прямой речи (явления главного предложения; дейксис, ориентированный на внутреннего говорящего) или, во всяком случае, не имеет симптомов косвенной речи. Так, в приведенном выше примере, несмотря на отсутствие кавычек (которые, как уже было сказано выше, в японском языке опциональны), в составе цитаты имеется модально-экспрессивная частица уо, однозначно квалифицирующая цитату как прямую. Возможно, прямая цитата имеет бо́льшую независимость и не может быть однозначно квалифицирована как вложенная составляющая несмотря на то, что вводится цитационным союзом. Пока эти две причины мы можем выдвинуть лишь гипотетически, проверка этих предположений выходит за рамки настоящей статьи.

2.1.3. В единичных случаях цитационный союз опускается и авторская ремарка (или ее фрагмент, содержащий глагол) следует непосредственно за цитатой:

(6) 3.1 .58

go-ryooshin ni mo 「konkai, akiko wa o-yasumi $\sim \sim^{4} ! !$ aa harahet-ta!!!」

HON-родители DAT тоже этот.раз Акико тOP HON-отдых аa проголодаться-PST

kurai akaru-ku tsutae-te kure-tara,

настолько веселый-ADV передать-CNV AUX.BEN-COND

'Если бы [он] прямо так весело передал своим родителям, типа «в этот раз Акико не будет (букв. [у нее] выходной) !! аа... [я] проголодался»!!!'

2.1.4. В соответствии со стандартными японскими правилами релятивизации именная группа подлежащее-говорящий может быть вынесена в вершину относительного предложения - «NP ${ }_{1}$ который сказал/ подумал, что S». При релятивизации цитата полностью сохраняет статус индексальных элементов, явления главного предложения и проч. Так, в следующем примере в составе цитаты обращают на себя внимание не только контактоустанавливающая частица $n a$, но и нефонологическое эмфатическое удлинение окончания презенса -ruи в глаголе kidokusuru 'отказываться читать', это удлинение выполняет функцию так называемого «имитатива» (см. [Подлесская 2018]), с его помощью внешний говорящий, нарратор, намеренно утрированно передает эмоциональную установку внутреннего говорящего, ср. русск. Она страдает: «Во-от, он на мои письма не отвеча-ает...»:

(7) 1.3 .70

\begin{tabular}{|c|c|c|c|c|c|c|}
\hline $\begin{array}{l}\text { Uranaishi } \\
\text { гадалка }\end{array}$ & $\begin{array}{ll}i \quad \text { o } & \text { shi-te } \\
\text { АCC } & \text { делать-CNV }\end{array}$ & $\begin{array}{l}i-t a \\
\text { AUX.PRG-PST }\end{array}$ & $\begin{array}{l}\text { koro, } \\
\text { во.время }\end{array}$ & $\begin{array}{c}\lceil\text { kare kara } \\
\text { он от }\end{array}$ & $\begin{array}{l}\text { henji } g a \\
\text { ответ NOM }\end{array}$ & $\begin{array}{l}k o-n a-i \\
\text { приходить }\end{array}$ \\
\hline$n$ & es-u」 $\quad\lceil k i d c$ & oku-su-ruu & na $n$ & $d e s-u\rfloor$ & & yan-de \\
\hline
\end{tabular}

4 Мы сохраняем в транслитерации имевшийся в оригинале знак («тильда»), который в текстах блогов (и шире - в современной японской графике) выполняет функции, близкие к европейскому многоточию. 
s-are-ru o-kyakusama ga, oo-ku irassha-imash-ita.

делать-PASS-PRS HON-клиент NOM многий-ADV HON.быть-ADR-PST

'Когда [я] работала гадалкой, то у меня было много клиентов, которые обращались ко мне за советом, страдая, что «[Во-от,] он [мне] не отвечает», «[он моих писем] не чита-ает»...'

2.1.5. В контексте противопоставления цитата может топикализироваться, маркер топика в этом случае располагается непосредственно после цитационного союза. Такое оформление цитаты полностью соответствует общим японским правилам топикализации клауз и глагольных групп, см. [Алпатов, Аркадьев, Подлесская 2008, I: 443-444, II: 50-51]. В современном японском узусе комбинация цитационного союза, маркера топика и конверба потенциальной формы глагола iu 'сказать' - to wa ie - грамматикализовалась и имеет уступительное значение (этот сдвиг близок переосмыслению русских можно сказать и можно подумать как дискурсивных маркеров). Так, в следующем примере в предтексте говорящую пугали последствиями замужества, и она противопоставляет шок от этих запугиваний и отсутствие намерения выходить замуж (что, по логике вещей, должно было бы сделать эти запугивания для нее безразличными). Отсутствие намерения подается буквально как 'можно сказать, что я не имела намерения... '5

(8) 1.1 .185

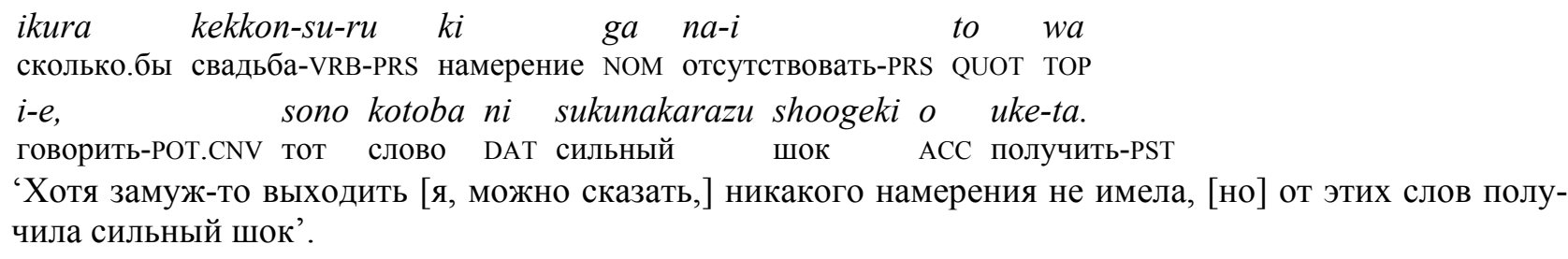

\section{2. Автономность цитаты}

2.2.1. В нарушение базового порядка слов авторская ремарка может помещаться в препозиции к цитате. При этом цитационный союз может сохраняться, как в (9), или опускаться - как в (10). При инверсии цитата заполняет семантическую валентность глагола речи, но приобретает синтаксическую автономию, которая еще больше усиливается, когда в составе препозитивной авторской ремарки имеется катафорическое местоимение, отсылающие к проецируемой цитате, ср. kоо 'так (спросил)’ в (10):

(9) 1.3 .183

De, wakaregiwa ni it-te mi-mash-ita.

так.вот на.прощание DAT говорить-CNV AUX.M-ADR-PST

「nanka , watashi, suki mitai de-su」 to.

что-то я влюбленность похоже COP.ADR-PRS QUOT

'Так вот, на прощание [я] сказала было: «Похоже 〜 , [ты] мне как бы нравишься»'

(10) 3.2 .86

Hitotoori kii-te kure-ta kare wa, koo kii-ta.

в.целом слушать-CNV AUX.BEN-PST он TOP так спросить-PST

「Sorede, kimi wa doo shi-ta-i no?」

итак ты тOP что делать-DSD-PRS PRT

'В целом, выслушав меня, он спросил так: «И что ты хочешь делать?»'

2.2.2. Автономность цитаты становится еще более очевидной в тех случаях, когда в конструкции отсутствует вводящий глагол. Ремарка может редуцироваться до указания на говорящего, которое может следовать как после цитаты, ср. (11), так и до нее, ср. (12). При этом цитационный союз может сохраняться, а может и опускаться, как в (13), и тогда цитирование происходит в формате «пьесы», когда реплика просто сопровождается именем действующего лица:

(11) 3.2 .96

「Un, $i-i \quad y o\rfloor$ to otto.
да хороший-PRS PRT QUOT
'«Да, хорошо!» мсказал] муж.'

${ }^{5}$ Мы благодарны анонимному рецензенту, справедливо указавшему на грамматикализацию этой конструкции в современном японском языке 
(12) 4.1 .127

Otto wa hitokoto, 「bimyoo」to.

муж тоР одно.слово странно QUOT

'Муж [сказал] одно слово: «странно»'.

(13) 4.2 .40

Tantei san, 「otto to wa rikon sa-re-ru no de-su ka? детектив HON муж с TOP развод делать-PASS-PRS NML COP.ADR-PRS Q

O-kosan no yoosu wa doo de-su ka?」

HON-ребенок GEN состояние TOP как COP.ADR-PRS Q

'Детектив [спросил]: «Вы будете разводиться с мужем? А как состояние ребенка?»'

2.2.3. Наконец, цитата может быть полностью автономной, если авторская ремарка отсутствует. Если при этом на ее правой границе имеется цитационный союз, то его не без основания принято считать заключительной частицей, поскольку он перестает выполнять функцию комплементайзера и приобретает значение эпистемической оценки - ссылки на чужие слова, см. [Прасол 1999], [Okamoto, Ono 2008]. Так, в (14) автор цитирует выдержки из чужого блога и снабжает каждую отдельную порцию процитированного текста завершающим tte в значении 'вот что там было сказано':

(14) 1.2 .182

$$
\sim \underset{\text { tochuuryaku }}{\sim \text { с.частичными.сокращениями }} \sim \sim
$$

Hakkiri i-ima-su. Kodomo, un-de gorannasai. Soo su-reba, hontoo no ai ga прямо говорить-ADR-PRS ребенок родить-CNV AUX.M.IMP так делать-COND истина GEN любовь NOM waka-ru yo, tte. um-u to, kono yo no koto mo, tannin no понимать-PRS PRT QUOT родить-PRS если этот мир GEN положение.дел тоже другие.люди GEN koto mo, jibun no koto mo, ai ga nani ka mo, waka-ru yo! tte. положение.дел тоже REFL GEN положение.дел тоже любовь NOM что Q тоже понять-PRS PRT QUOT ‘ Далее [цитирую] с сокращениями Скажу прямо. Родите ребенка! Если вы это сделаете, то поймете, [какова] истинная любовь, так [там сказано]. Если родите, то поймете и про мир, и про других людей, и про себя, и что это такое любовь! Так [там сказано]’.

Аналогичным образом устроен и пример (15). В предтексте есть гиперссылка на сайт некоего гуру по гаданию. Дальше цитируется его предсказание, за ним следует оценочный комментарий этого предсказания, который дает говорящая. Цитата без авторской ремарки завершается цитационным союзом to. Внутри оценочного комментария есть еще одно вхождение цитационного союза - на этот раз tte. Это вхождение демонстрирует полную прагматизацию союза - переход в статус тематической частицы с эпистемическим значением 'если говорить о...', которая может оформлять не только клаузы (как исходный сою3), но и именные группы. Согласно [Makino, Tsutsui 2009: 72-73], tte оформляет топикальную группу преимущественно в диалогическом режиме в эмоционально окрашенных контекстах. Ровно это мы и имеем в (15) - tte оформляет субстантивное анафорическое местоимение sore 'это', антецедентом которого является приведенная выше цитата:

(15) 1.1 .174

「Anta wa kekkon ni muite-na-i. Moshi kekkon shi-tara, aite wa, ты TOP женитьба DAT подходить.CONV.AUX.PRG-NEG-PRS Если женитьба делать-COND партнер тOP shin-u ka, byooki ni na-ru ka, atama okashi-ku na-ru ka gokudoo ni умереть-PRS или болезнь DAT стать-PRS или голова странный-ADV стать-PRS или мерзавец DAT na-ru」 to $O i$, oi, Sore tte ammari ja $n \quad \geqq \nabla \leqq)$. стать-PRS QUOT Ой, ой это TOP.QUOT слишком COP.PRS PRT '[Там сказано так:] «Ты не подходишь для брака. Если и выйдешь замуж, то твой партнер или умрет, или заболеет, или сойдет с ума, или станет мерзавцем». Ой-ой, это [такое предсказание ] уже

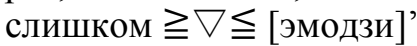

Наконец, цитата без заключительного цитационного союза/частицы и полностью авторской ремарки может занять присвязочную позицию во внешней клаузе:

(16) 2.1 .63

Amari kitai dekina-i koto o $i-u \quad$ no wa $\lceil$ nenshuu o слишком надежда не.мочь-PRS NML ACC говорить-PRS NML TOP годовой.заработок ACC 
ag-ete mora-u tameni, toriaezu kansha sh-ite ok-u $k a-」 d a$ поднять-CNV AUX.BEN-PRS чтобы прежде.всего благодарность делать-CNV AUX.O-PRS Q COP.PRS '[Вот на какие слова] можно особо не надеяться: «чтобы поднять заработок (у мужа), то не стоит ли начать с благодарности»' (букв. 'то, на что из сказанного не очень можно надеяться, это [такие слова]: «...»').

\section{3. Присубстантивная цитата}

Цитата может вводиться не глаголом (речи, мысли, чувства), а именем тех же семантических классов. В этом случае используется не цитационный союз, а его атрибутивные аналоги - toyuu, стяженный вариант tena и ряд других, — и синтаксически цитата становится атрибутом вводящего ее имени. Атрибутивные аналоги цитационного союза восходят исторически к грамматикализованному сочетанию определительной формы базового глагола речи iи ‘сказать' и самого́ цитационного союза to:

(17) 4.2 .58

$\lceil$ deki-ru koto nara rikon shi-taku-na-i」 toyuu o-kimochi de мочь-PRS NML если развод делать-DSD-NEG-PRS QUOT.ATR HON-расположение.духа INS

irai-sa-re-te ki-ta tsuma da-tta.

просьба-VRB-PASS-CNV AUX.DIR-PST жена COP-PST

'«Если это возможно, [я] не хотела бы разводиться», - с таким расположением духа [с расположением духа, которое можно сформулировать такими словами] обратилась [ко мне его] жена'.

(18) 2.3 .46

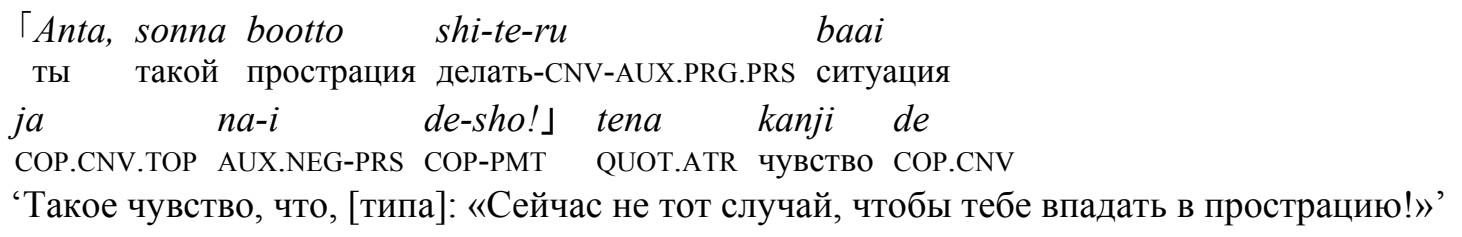

Итак, мы рассмотрели основные структурные свойства конструкции с цитационным союзом которыми его аналогами. Мы убедились, что в реальном узусе наблюдаются отклонения от протипического паттерна этой конструкции, эти отклонения могут регулироваться стандартными правилами японского синтаксиса или являться следствием контекстной редукции конструкции в живом некодифицированном дискурсе. В частности, с обследованном массиве текстов было обнаружено, что если подлежащееговорящий не эллиптируется, то оно чаще располагается левее цитаты, хотя цитату, как более тяжелую составляющую, в левоветвящемся языке можно было бы ожидать левее подлежащего. Далее, авторская ремарка имеет тенденцию редуцироваться: все три конституирующих ее элемента - говорящий, адресат и глагол речи - могут полностью или частично опускаться. Если ремарка отсутствует полностью, то цитационный союз либо опускается, либо его функция меняется - он функционально превращается в заключительную прагматическую частицу. Наконец, цитата может вводиться не глаголом, а именем со значением вербального (ментального, эмоционального) действия/процесса/состояния. В этом случае цитата с грамматической точки зрения является атрибутом имени и вводится атрибутивным аналогом цитационного союза.

Как уже говорилось во вводном разделе, структурные правила построения цитационной конструкции в равной мере применимы и к цитатам, построенным с дейктической точки зрения в прямом регистре (конструкциям с так называемой внутренней ориентацией, т. е. с ориентацией на внутреннего говорящего), и к цитатам, построенным в косвенном регистре (конструкциям с так называемой внешней ориентацией, т. е. с ориентацией на внешнего говорящего). В следующем разделе мы обсудим лексико-грамматические симптомы прямой и косвенной речи в обследованном нами массиве текстов.

\section{3. Симптомы прямой и косвенной речи}

В данном разделе мы представим (вынужденно краткий) обзор задокументированных в нашем рабочем массиве прагматически маркированных языковых средств, позволяющих оценить дейктическую перспективу цитаты, т. е. указывающих, на внутреннего или на внешнего говорящего ориентированы индексальные выражения в цитате.

Как уже говорилось выше, в японском языке нет ряда важнейших для языков среднеевропейского стандарта средств дифференциации прямой и косвенной речи: нет личного согласования, нет системы 
грамматически обязательного согласования времен, личные местоимения употребляются достаточно редко. Однако японский отнюдь не лишен средств указания на дейктическую перспективу — в этой функции используется система форм вежливости, многообразные экскламативы, конструкции со вспомогательными глаголами пространственной ориентации относительно одного из локуторов, конструкции со вспомогательным глаголами, указывающими на заинтересованность одного из локуторов в осуществляемом действии (бенефактивы), особое рефлексивное местоимение jibun, которое может употребляться для отсылки к внутреннему говорящему, наречия эпистемической оценки, ориентированной на говорящего, типа yappari 'согласно [моим] ожиданиям', и ряд других средств. Примечательно, что эти средства не обязательно действуют согласованно: в цитате часть индексальных выражений может быть ориентирована на внутреннего говорящего, а другая часть - на внешнего. В ставшей уже классической работе Куно Сусуму [Кuno 1988] были исследованы основные паттерны такого индексального рассогласования. Приведем для иллюстрации один пример из этой работы:

(19) Цитируется по [Kuno 1988: 83]

Taro wa yatsu no uchi ni nanji ni ko-i to it-ta no ka

Tаро TOP этот.парень GEN дом DAT в.котором.часу DAT приходить-IMP QUOT говорить-PST PRT Q

'На который час Таро «Приходи!» сказал?’

В пользу того, что перед нами прямая речь, говорит употребление непочтительной императивной формы koi 'приходи давай'. Вместе с тем, анафорическое выражение yatsu '[этот] парень' отсылает ко внутреннему говорящему - Таро, т. е. анафор ориентирован по косвенному паттерну — иначе было бы «Приходи домой ко мне», а не «к нему = к этому парню». Смешение перспектив усугубляется тем, что вопросительное местоимение nanji 'когда, в котором часу' в японском языке всегда имеет сферой действия матричную клаузу, даже если оно линейно появляется в составе вложенной клаузы. Поэтому оно ориентировано не на внутреннего говорящего, а на внешнего, т. е. на нарратора, оно не могло быть в таком виде употреблено в исходном вопросе, который процитирован: исходное речевое событие состояло в том, что Таро произнес приглашение к определенному времени, типа «Приходите ко мне в таком-то часу». И теперь нарратор запрашивает информацию о времени приглашения. Таким образом, конфигурация индексальных выражений в японской цитационной конструкции может оказаться весьма причудливой. Ниже мы кратко охарактеризуем основные классы дейктически маркированных языковых выражений, которые встретились в нашем корпусе.

\section{1. Конструкции и отдельные грамматические формы, кодирующие директивные речевые акты - просьбы, советы, запрещения}

В русском и многих других языках средневропейского стандарта грамматические формы и конструкции, кодирующие директив, могут обладать разной степенью синтаксической подчинимости. Так, собственно императивные формы являются синтаксически неподчинимыми, т. е. относятся к явлениям главного предложения, поэтому исходное высказывание с императивом не может быть передано в формате косвенной речи, ср. правильное Петя крикнул: «Не заходите!» и неправильное *Петя крикнул, что не заходите. Синтаксически неподчинимыми являются и директивы, выраженные инфинитивом, ср. правильное Петя крикнул: «Не заходить!» и неправильное *Петя крикнул, что не заходить. Однако пермиссивы/прохибитивы, выраженные, например, предикативными конструкциями с можно/нельзя, не относятся к явлениям главного предложения и в неизменной форме входят и в прямые, и в косвенные цитаты, ср. одинаково грамматичные Петя крикнул: «Заходить нельзя!» и Петя крикнул, что заходить нельзя.

В японском языке, как мы уже неоднократно упоминали, любая цитата - как с внешней, так с внутренней дейктической ориентацией - вводится комплементайзером, а в глагольных формах нет личночислового согласования. Поэтому употребление формы директива не определяет само по себе статус цитаты как прямой или косвенной. Т. е. часто складывается ситуация, как с русским заходить нельзя - за вычетом комплементайзера: только контекст может указать, имеем ли мы дело с речевым актом директива (прямая речь) или с сообщением о директиве (косвенная речь). Нейтрализация противопоставления «прямая/косвенная речь» особенно ощутима при употреблении несобственно императивных форм гортативов, предикативов со значением прохибитива/пермиссива, совмещающих директивную семантику с оценочной, и им подобных. Так, в следующем примере иллокутивное значение мягкой рекомендации выражается глагольной конструкцией финитная форма глагола $V+h o o g a$ ii 'лучше бы сделать $V$ ' (букв. $V$ + 'сторона' + NOM + 'быть хорошим'). Здесь нет никаких контекстных сигналов, которые позволили бы предпочесть прямую или косвенную интерпретацию: 
(20) 4.2 .18
Rikon no hookoo ni kangae-te i-ru tsuma rikon wa shi-na-i
развод GEN направление DAT думать-CNV AUX.PRG-PRS жена развод TOP делать-NEG-PRS
hoo ${ }^{1} \mathrm{ga}^{2} \mathrm{ii}^{3}$ to $i-u$ tantei san no yaritori de-su.
лучше.бы.PRS ${ }^{1,2,3}$ QUOT говорить-PRS детектив HON GEN спор COP.ADR-PRS
(i) 'Жена, которая склоняется к разводу, спорит с детективом, который говорит, что лучше не раз- водиться'
(ii) '...который говорит: «Лучше бы [вам] не разводиться»'

Вместе с тем, собственно императивные формы являются более прагматически маркированными: в частности, они имеют разветвленную градацию по вежливости и часто по степени вежливости императива можно соотнести его с этикетным статусом локуторов. Так, в следующем примере нарратор - женщина, внутренний говорящий - мужчина, в цитате использована грубая мужская синтетическая форма императива, которая не могла бы быть употреблена нарратором, и таким образом, диагностируется прямая цитата:

(21) 4.2 .35

Otto wa ... rikon-shi-ro to, moo ya-tte ik-e-na-i to semat-te i-ta муж TOP развод-VRB-IMP QUOT уже делать-CNV AUX.DIR-POT-NEG-PRS QUOT настаивать-CNV PRG-PST 'Муж стал настаивать: «Давай разводись! Так больше не могу»'

А в примере ниже употреблена нейтрально-почтительная аналитическая форма императива, принятая между чужими при запросе, направленном от равного к равному или от низшего к высшему, в том числе в институциональном дискурсе; в данном случае внутренний говорящий - заказчик, внутренний адресат - (частный) детектив, он же - внешний говорящий, нарратор. О том, что перед нами прямая цитата дополнительно свидетельствует и прямое обращение к нарратору внутри цитаты 'господин детектив':

(22) 4.1 .39

40-sai no otto kara irai ga ari-mashi-ta. 「Tantei san, 40-летний GEN мужчина от заказ NOM есть-ADR-PST детектив HON

kondo no suiyoobi no yoru, tsuma o oikake-te kudasai...」 этот.раз GEN среда GEN ночь жена АCC следить-CNV AUX.IMP

'[Я] получил заказ от 40-летнего мужчины: «Господин детектив, проследите за моей женой в ночь на эту среду...»'.

Таким образом, грамматические формы императива могут во многих (но не во всех!) случаях помочь диагностировать цитату как ориентированную на внутреннего или на внешнего говорящего.

\section{2. Бенефактивы}

Дифференциации прямой и косвенной речи в значительной части контекстов помогает наличие аналитических бенефактивных конструкций. Эти конструкции обозначают осуществление действия в интеpecax некоторого лица. Вспомогательный глагол в таких конструкциях выбирается из группы глаголов со значением 'давать/получать', причем выбор связан с тем, как соотносятся с говорящим исполнитель действия и бенефициант по признаку «свой/чужой» и «высший/равный/низший» на шкале социальных и ролевых стереотипов, см. подробнее [Алпатов, Аркадьев, Подлесская 2008, 1: 336-353]. Так, в следующем примере использован вспомогательный бенефактивный глагол kureru, который выбирается, если бенефициантом является говорящий (или лицо, ассоциированное с говорящим), а исполнителем действия - лицо, которого говорящий считает не выше себя. В данном случае цитата оказывается ориентирована на говорящего-мужчину, который представлен как лицо, в интересах которого происходит «внимательное слушание» (меня внимательно слушают). При этом исполнитель (исполнители) действия прямо не упомянутый в тексте! — не превосходит говорящего в статусе. Совокупность этих сведений позволяет интерпретировать цитату как прямую:

(23) 1.3 .125

\begin{tabular}{|c|c|c|c|c|c|}
\hline $\begin{array}{l}\text { Dansei } \\
\text { мужчина }\end{array}$ & $\begin{array}{l}w a \\
\text { TOP }\end{array}$ & $\begin{array}{l}\ldots \quad\lceil\text { chanto } \\
\quad \text { внимательно }\end{array}$ & $\begin{array}{l}\text { kii-te } \\
\text { слушать-CNV }\end{array}$ & $\begin{array}{l}\text { kure-te } \\
\text { AUX.BEN-CNV }\end{array}$ & $\begin{array}{l}i-r u ! 」 \\
\text { AUX.PRG-PRS }\end{array}$ \\
\hline
\end{tabular}

чувствовать-PRS когда очень радостный-PRS NML COP.ADR-PRS

'Если мужчины понимают (букв. чувствуют): «[Меня] внимательно слушают!», то [они] очень радуются'. 
Возможный вклад бенефактивных конструкций в статус цитаты хорошо виден в следующем примере (24), где имеются две цитаты с двумя разными бенефактивными глаголами. Первая цитата вводится глаголом речи $i u$ в пассиве iwareru '[ею] сказано'. Это слова женщины, адресованные супругу — 'Я не люблю тебя такого, каков ты сегодня. Если сделаешь то-то и то-то, тогда полюблю тебя’. Глагол aisuru '(по)любить' употреблен в бенефактивной конструкции со вспомогательным глаголом ageru, который обозначает действие говорящего, совершаемое в интересах лица, которого говорящий позиционирует как равного себе или выше себя в социальной или ролевой иерархии. Этот глагол по степени этикетной вежливости уместен в женской речи и позволяет квалифицировать данную цитату как прямую передачу слов говорящей. Дополнительным подтверждением ориентации цитаты на говорящую служит употребление местоимения второго лица anata 'ты', которое тоже имеет достаточный уровень этикетной вежливости, чтобы употребляться от лица женщины; более того, согласно [Алпатов, Аркадьев, Подлесская 2008, 1: 480], anata является практически обязательным местоимением второго лица при обращении к мужу. Вторая цитата — передача не реального высказывания, а внутреннего монолога супруга. Она, как и первая цитата, вводится с помощью цитационного союза $t t e$, но подчиняется не глаголу речи, как в первом случае, а глаголу пағи 'получиться так, что...', и вся конфигурация может интерпретироваться так: «сложится такая ситуация, которую можно описать следующими словами...». Слова, описывающие сложившуюся ситуацию, переданы с помощью бенефактивного глагола yaru, который обозначает действие, осуществляемое говорящим в интересах бенефицианта, стоящего ниже говорящего на социальной или ролевой лестнице. Подразумеваемый невысокий статус бенефицианта делает конструкцию с данным глаголом достаточно грубой, она более свойственна мужской речи. Соответствующий бенефактив от глагола suneru 'обижаться, сердиться, дуться' - sunete yaru - означает 'я [на нее] обижусь', причем 'она' характеризуется как нижестоящая в иерархии. В пользу прямой интерпретации этой цитаты помимо бенефактивной конструкции, ориентированной на внутреннего говорящего, свидетельствует и заключающая цитату последовательность восклицательной частицы mon 'pазве (не)' и вопросительной частицы $k a$; частицы добавляют эмфатический компонент значения - говорящий сокрушается «и что же? мне останется лишь такой нелегкий выбор?» (подробнее о частицах в составе цитаты см. раздел 3.4):

(24) 2.1 .21

$\begin{array}{lllllll}\text { Ima no anata ja } & \text { ai-se-na-i. } & \text { Kore o shi-tara ai-sh-ite } & \text { age-ru.」 } \\ \text { сейчac GEN ты } & \text { PRT } & \text { любить-VRB.POT-NEG-PR } & \text { это ACC делать-COND любить-VRB-CNV AUX.BEN-PRS } \\ \text { tte } i w \text {-are-ru } & \text { to, ai-s-are-ru } & \text { tame ni gambat-te yaritoge-ru } k a,\end{array}$

QUOT говорить-PASS-PRS COND любить-VRB-PASS-PRS чтобы DAT стараться-CNV достичь-PRS Q

sune-te yar-u mon ka! tte nar-u ka no dochira ka na no sa. обижаться-CNV AUX.BEN-PRS PRT Q QUOT получиться-PRS Q GEN что-то Q PRT NML PRT 'Если [женщина] скажет [тебе] (букв. употреблен пассив 'если будет сказано'): «[Я] не могу любить тебя [такого, каков ты] сегодня. Если сделаешь то-то и то-то, тогда полюблю тебя», то что тебе [останется]? Получится, типа, или буду стараться сделать [что она попросила] ради любви, или обижусь [на нее и ничего этого делать не буду]!'.

Интересно, что вторая цитата в (24) оформлена графически иначе, чем первая - она не обрамлена кавычками, но завершается восклицательным знаком. Складывается ситуация, которую в русистике принято называть несобственно-прямой речью, см. [Ковтунова 1955/2010], — внутрь повествования вставлен фрагмент, передающий мысли и чувства персонажа, но не оформленный графически как цитата. Как мы уже упоминали в разделе 1 , кавычки в японском языке не обязательны и надежным диагностическим признаком прямой цитаты быть не могут, особенно в таком слабо нормированном жанре электронного неформального дискурса, как блог. Тем не менее обращает на себя внимание тот факт, что из двух последовательно приведенных цитат первая вводит артикулированную речь и оформлена кавычками, а вторая вводит воображаемый внутренний монолог и обходится без кавычек.

\section{3. Референциальная отсылка к локуторам и третьим лицам в составе цитаты: полные имен- ные группы, личные и указательные местоимения, возвратное местоимение дзибун}

Ориентация индексальных элементов на внутреннего или на внешнего говорящего проявляется в выборе способа отсылки к локуторам и третьим лицам в составе цитаты. Личные местоимения, как уже говорилось в разделе 1 , в японском языке гораздо менее частотны, чем в языках среднеевропейского стандарта, однако они достаточно разнообразны и, что еще более важно для установления статуса цитаты - различаются по этикетной вежливости, с учетом уже упоминавшихся противопоставлений по признаку «свой/чужой» и «высший/равный/низший» на шкале социальных и ролевых стереотипов, см. под- 
робнее [Алпатов, Аркадьев, Подлесская 2008, 1: 472-489]. Так, в примере (24) выше мы уже видели, что при цитировании слов женщины, обращенных к супругу, статус цитаты как прямой подкреплен употреблением местоимения второго лица anata - стандартным способом референциальной отсылки к слушающему, если слушающий - муж говорящей. В следующих двух примерах с очевидной прямой цитацией употреблены два разных местоимения первого лица - в (25) грубое мужское ore, а в (9), повторенном ниже как (26), — преимущественно женское watashi:

(25) 3.1 .132

Hitotoori, hananshi-oe-te kare ga it-ta 「ore wa doo shi-tara i-i」 более-менее говорить-закончить-CNV он NOM говорить-PST я TOP что делать-COND хороший-PRS 'После того как мы более-менее закончили говорить, он сказал: «Что мне лучше сделать?»'

(26) 1.3.181

De, wakaregiwa ni it-te mi-mashi-ta.

так.вот на.прощание DAT говорить-CNV AUX.M-ADR-PST

$\lceil$ nanka $\sim$, watashi, suki mitai des-u」 to.

это.самое я нравиться типа COP.ADR-PRS QUOT

'Так вот, на прощание [я] сказала было: «Похоже , [ты] мне как бы нравишься»'

Диагностическими могут являться именования родственников, которые в японском языке также часто прагматически маркированы: для обозначения супругов, родителей, братьев-сестер и ряда других родственников говорящего используются способы именования, отличные от именования родственников слушающего и родственников третьих лиц. Так, в следующем примере вне цитаты жена именуется нейтрально-почтительным okusan, а внутри прямой цитаты мужчина говорит о своей жене tsuma:

(27) 4.1 .11

Okusan to sekkusuresu no otto, 「tsuma dewa moo dame da hoka no

жена с без.секса GEN муж жена TOP уже нельзя COP.PRS другой GEN

josei to shi-ta-i」 tte $i-u$ otto,

женщина с делать-DSD-PRS QUOT говорить-PRS муж

'Мужья, которые не имеют сексуальных отношений с женой, мужья, которые считают «с женой больше никак хочу попробовать с другой женщиной»'.

В составе цитаты вместо местоимений второго лица часто используются обозначения слушающего в третьем лице. Согласно [Алпатов, Аркадьев, Подлесская 2008, 1: 486-487], в ситуации минимальной этикетной вежливости собеседник обычно именуется по имени, фамилии, должности, профессии или статусу родства с добавлением показателя вежливости san. Так, в следующем примере два действующих лица: нарратор, девушка по имени Норико (она же - внутренний слушающий) и внутренний говорящий, ее возлюбленный, слова которого, обращенные к ней, Норико цитирует. В авторской ремарке Норико именует своего возлюбленного в третьем лице daarin '[мой] дорогой, darling'. Цитата строится как прямая речь: внутренний говорящий, daarin, (i) в отношении себя использует строго мужское местоимение первого лица $b o k u$, (ii) в отношении Норико при обращении к ней как ко внутреннему слушающему использует не местоимение второго лица, а сочетание имени с показателем вежливости - Noriko san, (iii) условная форма бенефактива kite kuretara 'если бы [ты ко мне] приходила' образуется сочетанием полнозначного глагола со значением 'приходить' и условной формы уже упоминавшегося выше вспомогательного бенефактивного глагола kureru, который выбирается, если действие совершается в интересах говорящего:

(28) 1.1 .9

Tsuukin ga kanari too-ku nar-u nimokakawarazu, 「boku ga,

служба NOM довольно далекий-ADV стать-PRS несмотря я NOM

wanruumu manshon o kari-te, Noriko san chi no chika-ku ni sum-u wa .

одна.комната жилье ACC снять-CNV Норико HON дом GEN близкий-ADV DAT жить-PRS PRT

Mainichi $j a$ na-kutemo $i$ - $i, \quad$ shigoto no aima ni

Каждый.день COP.CNV.TOP AUX.NEG-CNC хороший-PRS работа GEN между DAT

ki-te kure-tara i-i yo」 to it-te kure-ta daarin

прийти-CNV AUX.BEN-COND хороший-PRS PRT QUOT говорить-CNV AUX.BEN-PST дорогой

'Несмотря на то, что ему до службы будет далеко добираться, [мой] дорогой [был тем, кто] сказал: «Я сниму однокомнатное жилье и буду жить рядом с твоим домом (букв. с домом Норико сан) . Пусть и не каждый день, [ты] бы приходила [ко мне] во время перерыва, как было бы хорошо»'. 
В качестве отсылки к внутреннему говорящему вместо местоимения первого лица может использоваться дистантный рефлексив jibun. В своем стандартном употреблении этот рефлексив отсылает к субъекту текущей или объемлющей клаузы, если на этот субъект распространяется эмпатия говорящего [Алпатов, Аркадьев, Подлесская 2008, 2: 104-115], при этом в текущей клаузе референт рефлексива имеет семантический статус пациенса [Makino, Tsutsui 2009: 159-163]. Парадоксальным образом, рефлексив только осуществляет анафорическую отсылку к внутреннему говорящему, но не маркирован относительно прямой/косвенной интерпретации цитаты, т. е. в (29) ниже цитата может быть интерпретирована и как прямая '[эта женщина/жена] мной не интересуется', и как косвенная '[эта женщина/жена] им не интересуется’:

(29) 1.3 .221

$\lceil J i b u n$ ni kanshin ga na-i」 to omo-u to, dansei wa hii-te REFL DAT интерес NOM быть-NEG-PRS QUOT думать-PRS COND мужчина тOP уходить-CNV

shima-imas-u yo.

AUX.S-ADR-PRS PRT

i. 'Если мужчина думает: «[Эта женщина/жена] мной не интересуется», то он уходит'.

ii. 'Если мужчина думает, что [эта женщина/жена] им не интересуется, то он уходит'.

Внутри одной и той же цитаты отсылка к внутреннему говорящему может осуществляться как дейктически нейтральным рефлексивом jibun, так и дейктически маркированным личным местоимением. В примере ниже наряду с jibun употребляется грубое мужское местоимение первого лица оre, которое однозначно маркирует цитату как дейктически прямую, с чем согласуется и бенефактив ite yaru, образованный от полнозначного глагола iru 'быть' с использованием уже упоминавшегося вспомогательного глагола yaru - свойственного мужской речи и обозначающего действие говорящего, которое затрагивает бенефицианта, стоящего ниже говорящего на социальной или ролевой лестнице (в данном случае адресата ) - «тебя затронет то, что я останусь таким, как есть»:

(30) 2.1 .30

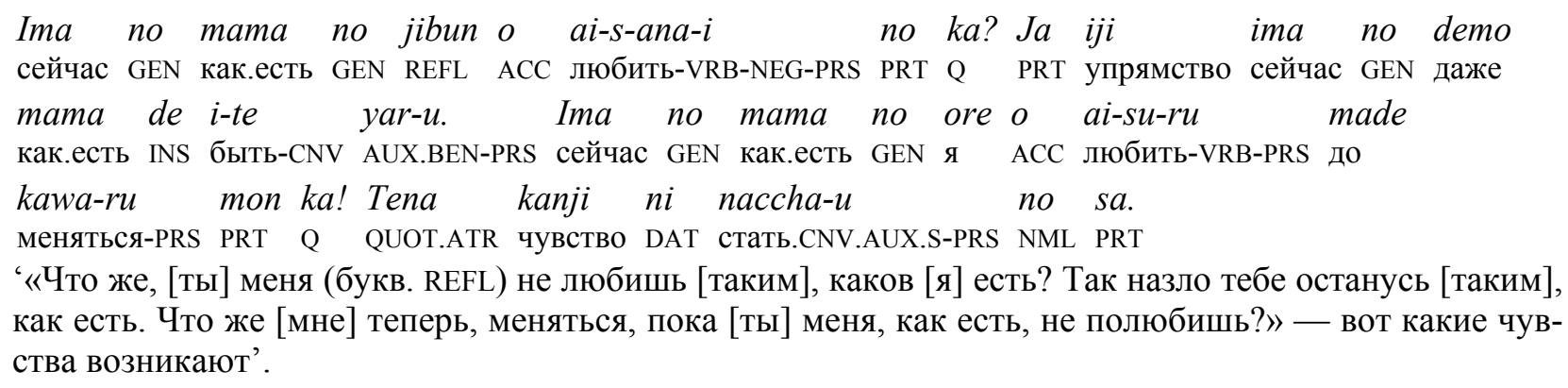

В приведенном выше примере статус цитаты как дейктически прямой поддерживается и модальноэкспрессивными частицами, в частности последовательностью частиц $m o n \mathrm{ka}$, передающей недоуменновозмущенный вопрос «разве (не)?», «что же?». О такого рода единицах речь пойдет в следующем разделе.

\section{4. Экскламативы}

Безусловными симптомами прямой речи являются единицы, которые можно объединить под рубрикой «экскламативов». Все они могут быть отнесены к «явлениям главного предложения», о которых шла речь в разделе 1. В первую очередь, это модально-экспрессивные частицы, стандартно занимающие крайнюю правую позицию в клаузе. В бытовой разговорной речи, особенно в диалогическом режиме, практически каждый дискурсивный шаг завершается одной из таких частиц или их группой, см. [Алпатов, Аркадьев, Подлесская 2008, 1, 462 - 463], [Прасол 1999]. Так, в (31) о прямой цитации свидетельствует заключительная частица уо, которая, согласно [Makino, Tsutsui 2009: 543-547], передает значение уверенности говорящего, причем эта уверенность опирается на его собственное знание или мнение, ср. «Говорю тебе, делать ничего не надо!»:

(31) 3.2 .81

Nanimo shi-na-kute $i$-i yo to kare wa it-te kure-ru ничего делать-NEG-CNV хороший-PRS PRT QUOT он TOP сказать-CNV AUX.BEN-PRS

'Он сказал [мне]: «Ничего не надо делать!»'. 
Частица уо и другие частицы этого класса представлены также в примерах предыдущих разделов, см. (1), (3), (5), (7), (10), (11), (14), (24), (28), (30).

К экскламативам можно отнести также междометия, нефонологические эмфатические удлинения звуков и ряд других подобных средств. В примере (32) употреблено вопросительное местоимение nani ‘что' в эмфатическом варианте - с удлинением гласного:

(32) 3.2 .58

$\lceil$ Naani?」 to kapibara-san.

что QUOT Капибара-сан

‘«Чтоо?» [сказал] Капибара'.

В примере (33) использовано междометие удивления $e$ 'как это?!' в варианте с нефонологическим эмфатическим удлинением гласного. Интересно, что между цитатой и комплементайзером расположен один из многочисленных японских смайликов каомодзи - $\geqq \unlhd$ Существенно, что эта «улыбка» передает отношение внешнего, а не внутреннего говорящего: цитируется мысль, т. е. оригинальная версия внутренней речи не могла содержать графического компонента. Таким образом, внутрь прямой цитаты проник элемент, прагматически ориентированный по косвенному типу — на внешнего горящего:

(33) 1.3 .187

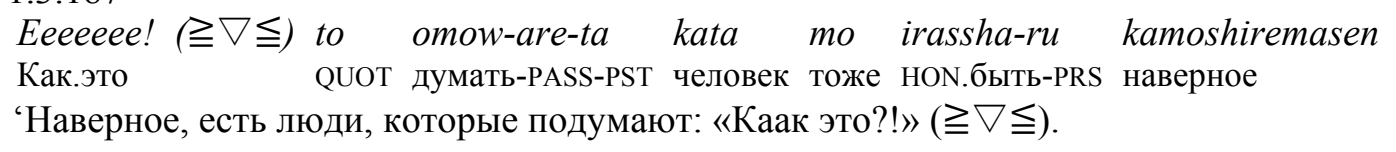

Таковы некоторые грамматические и лексические симптомы, которые позволяют увидеть в цитате ориентацию на внутреннего или на внешнего говорящего. В следующем разделе мы постараемся показать, как данные японского языка могут оказаться полезными для систематизации межъязыковой вариативности цитационных конструкций.

\section{4. Заключение: типологические уроки}

Мы постарались показать, что в японском языке прямая и косвенная речь не образуют бинарного противопоставления. С грамматической точки зрения нейтрализующим фактором является то, что независимо от того, как выбираются индексальные выражения, цитата вводится комплементайзером (цитационным союзом). Причем грамматическая нейтрализация сохраняется независимо от того, каким преобразованиям (е.g. релятивизации, эллипсису, линейным передвижениям и проч.) подвергается исходная прототипическая структура цитационной конструкции в живой речи. С точки зрения прагматики/дейксиса нейтрализующими являются следующие факторы:

1. В японском языке нет лично-числового согласования, обязательных требований согласования времен, особых правил порядка слов в зависимой клаузе.

2. Другие возможные типы индексальных выражений (бенефактивы, показатели вежливости, средства поддержания референции, отсылающие к локуторам) не являются ни обязательными, ни даже высокочастотными, поэтому цитата может вообе не содержать сигналов, указывающих на то, прямая она или косвенная.

3. Даже если такие сигналы есть, они не обязательно действуют согласованно. Например, цитата может содержать императив, т. е. содержать показатель иллокутивной силы, отличной от сообщения, - это говорит о прямой цитате. Однако из множества императивных форм, различающихся в японском языке по этикетной вежливости, может быть выбрана форма, не соответствующая по этикетности внутреннему говорящему. Скажем, нарратором (внешним говорящим) и его слушающим в неформальной бытовой беседе являются молодые мужчины; нарратор цитирует слова женщины (внутренней говорящей); ее оригинальное высказывание было построено как директив с использованием императивной формы; в оригинальном высказывании должен был использоваться женский вежливый императив; однако в цитате используется другая императивная форма, дейктически ориентированная на нарратора - т. е. грубая мужская. Итог: иллокутивная сила (директив) в цитате сохранена, однако признать ее безусловно прямой мешает то обстоятельство, что форма вежливости выбрана, как в косвенной речи.

Наконец, следует добавить, что, даже если все грамматические и прагматические факторы свидетельствуют о том, что перед нами прямая цитата, она не обязательно является буквальным воспроизведением оригинального высказывания (на японском материале это было показано, например, в [Itakura 2019]). 
Все это вместе свидетельствует о том, что противопоставление прямой и косвенной речи в японском языке не вписывается в прототип, знакомый по языкам среднеевропейского стандарта. Исследования языков за пределами ареала распространения «среднеевропейского стандарта» показывают, что значения параметров цитационных конструкций могут устойчиво кластеризоваться различными способами. В частности, весьма распространены такие стратегии цитации, при которых синтаксические и дейктические параметры не согласованы. Это могут быть конструкции, в которых цитата имеет статус подчиненной клаузы, а часть индексальных выражений в составе цитаты, прежде всего подлежащее, ориентированы на внутреннего говорящего, т. е. дейксис - как в прямой речи, ср.: [Перехвальская 2020] - об удэгейском языке, [Князев 2017] — о башкирском, [Yaroshevich 2019] — о табасаранском, [Сумбатова 2019] — о даргинском. Или, наоборот, цитата не демонстрирует признаков синтаксического подчинения, а часть индексальных выражений в составе цитаты не следует ожидаемому прототипу прямой речи: для отсылки к внутреннему говорящему используются не местоимения 1-го лица, а особые индексальные выражения логофоры, или местоимения других классов, например рефлексивы, которые используются в функции логофоров, cp. [Nikitina, Bugaeva 2021] об айнском языке и языке ван (манде). Устойчивость и распространенность кластеров такого рода не позволяет рассматривать их как маргинальные отклонения от поляризованных канонов прямой и косвенной речи. Как мы могли убедиться, в японском также обнаруживаются подобные кластеры. Все это позволяет предположить, что для адекватного анализа межъязыкового варьирования цитационных конструкций следует отказаться от бинарного противопоставления прямой и косвенной речи в пользу более плодотворного многофакторного подхода, позволяющего учитывать все многообразие исследуемой зоны и выделять лингвоспецифические кластеры значений релевантных параметров.

В завершение - еще одно важное замечание. В этой работе мы рассмотрели только один способ построения цитаты в японском языке - с использованием цитационного союза. Однако возможен и другой способ - субстантивация, т. е. цитата строится как сентенциальное дополнение к глаголу речи/ мысли, а именно: предикация в цитате превращается именную группу путем присоединения субстантиватора (номинализатора) - грамматикализованного существительного с максимально обобщенной семантикой. Преобразуемая предикация формально является определением к субстантиватору: в соответствии с общими правилами оформления относительных придаточных в японском языке она непосредственно предшествует субстантиватору, а ее сказуемое имеет финитную индикативную форму. К субстантиватору справа при необходимости присоединяются те показатели, которые нужны, чтобы встроить цитату в главную клаузу. Так, в следующем примере имеются две однородных субстантивированных цитаты, обе вводятся субстантиватором koto 'вещь, факт, положение дел', первое koto - как первый компонент сочиненной группы - остается неоформленным, второе присоединяет маркер аккузатива $o$, который показывает, что оба сочиненных компонента синтаксически являются прямым дополнением глагола речи/передачи информации tsutaeru 'передавать, сообщать', семантически заполняют его валентность содержания («сообщила о том, что ... и о том, что ...»):

(34) 3.2 .81
kare ni wa wakar-ana-i mono ga ar-u koto, tonikaku, kore made он DAT TOP понимать-NEG-PRS NML NOM быть-PRS NML во.всяком.случае это до
zutto kanji-te ki-ta koto o guchagucha-ni nari-nagara tsutae-ta.
все.время чувствовать-CNV AUX.DIR-PST NML ACC хаотично-ADV стать-CNV передавать-PST
'[Я], путаясь, рассказала ему о том, что есть вещи, которые он не понимает, [и,] во всяком случае, о том, что я перечувствовала за все это время'.

Индексальные элементы в цитате, построенной с использованием субстантиватора, чаще всего ориентированы на внешнего говорящего, т. е. по косвенной модели; кроме того, эта стратегия более частотна, чем стратегия с комплементайзером, не при глаголах речи, а при глаголах мыслительной деятельности, мнения и т. п. Исследователи обращали внимание на сосуществование этих двух стратегий цитации ([Nakau 1973: 104-122], [Akatsuka McCawley Noriko 1978: 178-207], см. также [Алпатов, Аркадьев, Подлесская 2008, 2: 307-319] и библиографию там же), но в целом их дистрибуция еще ожидает своего детального исследования. Дополнительным возмущающим обстоятельством является то, что цитата может присоединяться к субстантиватору не непосредственно, а с помощью атрибутивных аналогов цитационного союза, о которых шла речь выше в разделе 2.3 , но при этом получившаяся сложная именная группа не заполняет валентность глагола речи/мысли. Так, в примере ниже имеется эквативная конструкция «...koto ${ }_{1}$ это почти то же, что... koto ${ }_{2}$; и первое, и второе koto субстантивируют предикацию, и оба присоединяются через атрибутивный аналог цитационного союза тоуии; вторая предикация представляет собой цитату без вводящего предиката речи, причем цитатность подчеркнута опциональными в общем случае кавычками: 
(35) 1.2 .104

47 sai no josei to kekkon su-ru toyuu koto wa, hobo,

47.лет GEN женщина с женитьба делать-PRS QUOT.ATR NML TOP почти

$\begin{array}{rllllllll}\lceil\text { kodomo } & \text { o } & \text { mot-ana-i } & (\text { mot-e-na-i) } & \text { jinsei } & \text { o } & \text { oku-ru」 toyuu } & \text { koto des- } u \\ \text { ребенок } & \text { ACC } & \text { иметь-NEG-PRS } & \text { иметь-POT-NEG-PRS } & \text { жизнь } & \text { ACС } & \text { вести-PRS } & \text { QUOT.ATR } & \text { NML COP.ADR-PRS. }\end{array}$

'Жениться на 47-летней женщине почти всегда [означает]: жить, не имея (не имея возможности иметь) детей.'

Использование разных стратегий цитации в современном неподготовленном дискурсе, в том числе электронном, пока еще изучено слабо — и это еще одно свидетельство того, что нам пока известны далеко не все детали того многосоставного пазла, каким является зона цитации в японском языке. Надеемся, что многофакторный подход, предложенный в данной работе, поможет восстановлению полной картины и сделает возможным ее сравнение с тем, что известно про стратегии цитации в других языках.

\section{Сокращения}
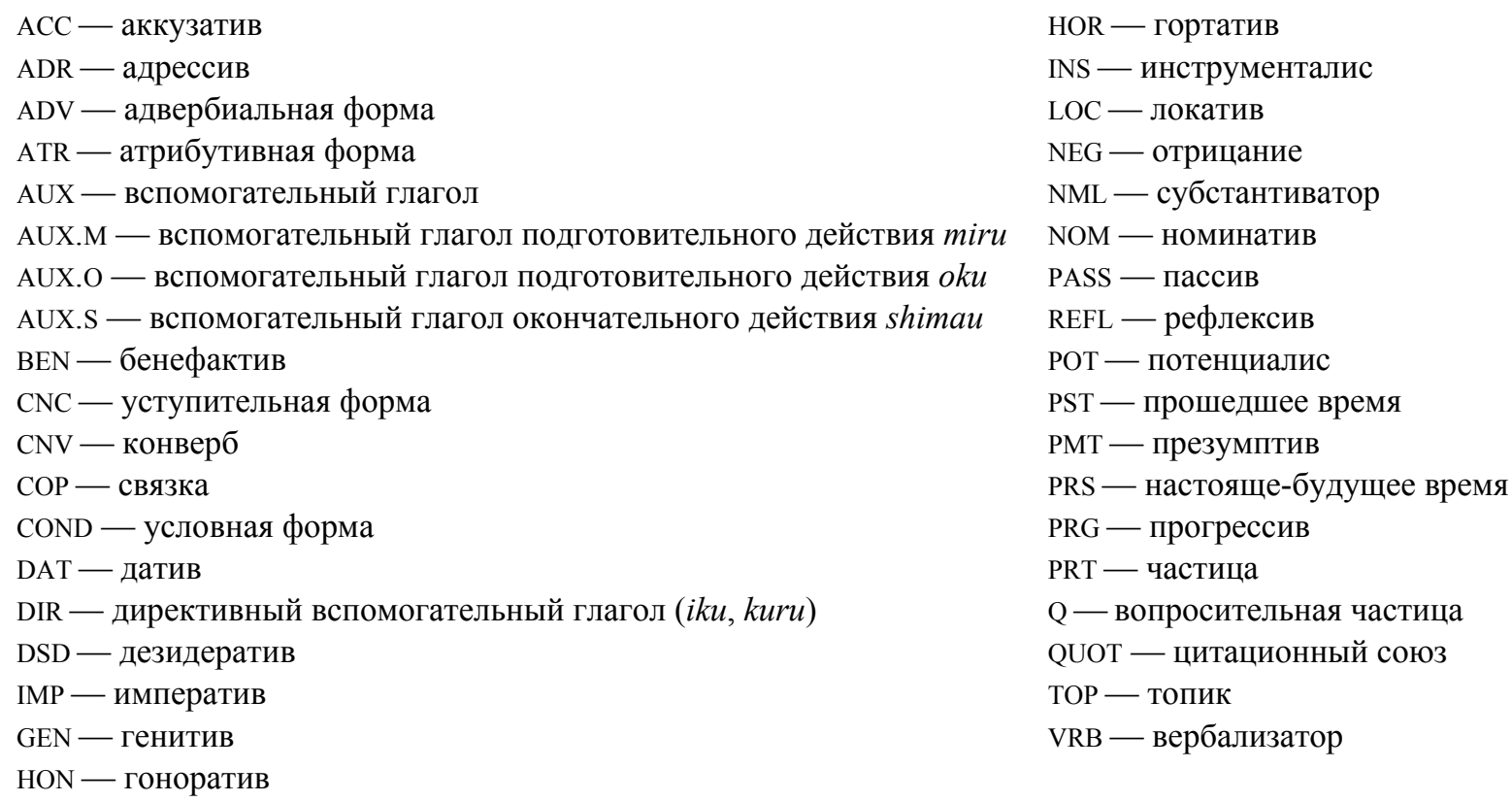

\section{Литература}

Алпатов, Аркадьев, Подлесская 2008 - Алпатов В. М., Аркадьев П. М., Подлесская В. И. Теоретическая грамматика японского языка. T. 1-2, М., 2008. \{Alpatov V. M., Arkadiev P. M., Podlesskaya V. I. Theoretical grammar of the Japanese language. Vol. 1-2. Moscow, 2008.\}

Князев 2017 - Князев М. Ю. Конструкции передачи чужой речи в башкирском языке // Acta Linguistica Petropolitana. Труды Института лингвистических исследований РАН / Отв. ред. Н. Н. Казанский. Т. ХІІІ. Ч. 1. СПб., 2017. C. 71-109. \{Knyazev M. Yu. Reported speech constructions in Bashkir // Acta Linguistica Petropolitana. Transactions of the Institute for Linguistic Studies, RAS / Ed. N. N. Kazansky. Vol. XIII. Part 1. St. Petersburg, 2017. P. 71-109.\}

Ковтунова 1955/2010 - Ковтунова И. И. «Несобственно прямая речь» в языке русской литературы конца XVIII первой половины ХІХ в. Вступ. ст., прил., указ. А. Г. Грек. М., 2010. (Дисс. ... канд. филол. наук. М., 1955.) \{Kovtunova I. I. "Free indirect speech" in the language of Russian literature at the end of the $18^{\text {th }}-11^{\text {st }}$ half of the $19^{\text {th }}$ centuries / Ed. A. G. Grek. Moscow, 2010.\}

Падучева 1996 - Падучева E. В. Субъективная модальность: иллокутивные показатели и вводные слова // Падучева E. В. Семантические исследования. М., 1996. С. 297-320. \{Paducheva E. V. Subjective modality: illocutionary indicators and introductory words // Paducheva E. V. Semantic studies. Moscow, 1996. P. 297-320.\}

Перехвальская 2020 - Перехвальская E. B. Репортативная речь в удэгейском языке и шире // Вопросы языкознания. 2020, 1. С. 84-103. \{Perekhvalskaya E. V. Reportative speech in Udihe and beyond // Topics in the study of language. 2020, 1. P. 84-103.\} 
Подлесская 2018 - Подлесская В. И. Чужая речь в свете корпусных данных // Вопросы языкознания. $2018,4$. C. 47-73. \{Podlesskaya V. I. Reported speech through the lens of corpus data // Topics in the study of language. $2018,4$. P. 47-73.\}

Прасол 1999 - Прасол А. Ф. Заключительные модально-экспрессивные частицы в японской речи. Учебное пособие. Владивосток, 1999. \{Prasol A. F. Final modal-expressive particles in Japanese speech. Tutorial. Vladivostok, 1999.\}

Сумбатова 2019 - Сумбатова Н. Р. Личный дейксис в цитационных конструкциях даргинского языка // Томский журнал лингвистических и антропологических исследований. 2019, 3 (25). С. 72—81. \{Sumbatova N. R. Personal deixis in the reported speech: the case of tanti Dargwa // Tomsk Journal of Linguistics and Anthropology. 2019, 3 (25). P. $72-81$.

Чиронов 2014 - Чиронов С. В. Японские иллокутивные глаголы в ремарочном употреблении: перспективы исследования // Филологические науки. Вопросы теории и практики. Тамбов. 2014, 5 (35), ч. 1. C. 197-205. \{Chironov $S$. $V$. The Japanese illocutionary verbs in note use: research prospects // Philology. Theory \& Practice. Tambov. 2014, 5 (35), part. 1. P. 197-205.\}

Ярошевич 2019 - Ярошевич С. We marry Alice: an unusual reported speech construction in Tabasaran // Международная конференция «Кавказские языки: типология и диахрония» памяти М. Е. Алексеева. 23 -24 октября 2019 г. Институт языкознания РАН, Москва: Тезисы докладов / Сост. И. Г. Багирокова, Т. А. Майсак. М., 2019. С. 88-90. \{Yaroshevich S. We marry Alice: an unusual reported speech construction in Tabasaran // International conference "Caucasian languages: typology and diachrony” in memory of M. E. Alekseev. October 23-24, 2019. Institute of Linguistics, RAS, Moscow: Abstracts / Comp. I. G. Bagirokova, T. A. Maisak. Moscow, 2019. P. 88—90.\}

Akatsuka McCawley Noriko 1978 - Akatsuka McCawley Noriko. Another look at no, koto and to: Epistemiology and complementaizer choice in Japanese // Hinds J., Howard I. (eds.). Problems in Japanese Syntax and semantics. Tokyo, 1978.

Evans 2013 - Evans N. Some problems in the typology of quotation: A canonical approach. Canonical morphology and syntax // Brown D., Chumakina M., Corbett G. G. (eds.). Oxford, 2013. P. 66-98.

Coulmas 1985 - Coulmas $F$. Direct and indirect speech: general problems and problems of Japanese // Journal of Pragmatics. 1985, 9. P. 41-63.

Güldemann 2008 - Güldemann T. Quotative indexes in African languages: a synchronic and diachronic survey. Empirical Approaches to Language Typology 34. Berlin, 2008.

Güldemann, von Roncador (eds.) 2002 — Güldemann T., von Roncador M. Reported discourse: A meeting ground for different linguistic domains. Amsterdam, 2002.

Hawkins 1994 - Hawkins J. A. A Performance Theory of Order and Constituency. Cambridge Studies in Linguistics 73. Cambridge, 1994.

Iwasaki 2013 - Iwasaki Shoichi. Japanese. Revised edition. [London Oriental and African Language Library, vol. 17]. Amsterdam — Philadelphia, 2013.

Itakura Hiroko 2019 - Itakura Hiroko. Accuracy in reported speech: Evidence from masculine and feminine Japanese language // Alessandro Capone, Una Stojnic, Ernie Lepore et al. (eds.). Indirect Reports and Pragmatics in the World Languages. Springer Verlag, 2019. P. 315-331.

Kuno Susumu 1988 - Kuno Susumu. Blended quasi-direct discourse // Papers from the Second International Workshop on Japanese Syntax / Ed. William J. Poser. Stanford (CA), 1988. P. 75-102.

Lobke et al. 2012 - Lobke A., Haegeman L., Nye R. (eds.). Main clause phenomena: New horizons. (Linguistik Aktuell / Linguistics Today, 190.) Amsterdam, 2012.

Makino, Tsutsui 2009 - Makino Seiichi, Tsutsui Michio. A Dictionary of Basic Japanese Grammar. Japan Times, 2009.

Maynard 1998 - Maynard Senko K. Ventriloquism in text and talk: Functions of self- and other-quotation in Japanese // Akatsuka Noriko, Hoji Hajime, Iwasaki Shoichi, Sohn S.-O., Strauss S. (eds.). Japanese/Korean Linguistics. V. 7. Stanford (CA), 1998. P. 17-37.

Nakau 1973 - Nakau Minoru. Sentential complementation in Japanese. Tokyo, 1973.

Nikitina, Bugaeva 2021 - Nikitina Tatiana, Bugaeva Anna. Logophoric speech is not indirect: Towards a syntactic approach to reported speech constructions // Linguistics. 2021, 59(3). P. 609-633.

Okamoto, Ono 2008 - Okamoto Shigeko, Ono Tsuyoshi. Quotative tte in Japanese: Its multifaceted functions and degrees of "subordination" // Ed. Ritva Laury. Crosslinguistic Studies of Clause Combining: The multifunctionality of conjunctions. [Typological Studies in Language 80]. Amsterdam — Philadelphia, 2008. P. 205-230.

Oshima 2006 - Oshima D. Y. Perspectives in Reported Discourse. PhD thesis, Stanford University, 2006.

Saito Hiroaki 2018 - Saito Hiroaki. The Monster Tells Where You Are // Wm. G. Bennett et al. (eds.) Proceedings of the $35^{\text {th }}$ West Coast Conference on Formal Linguistics, Somerville (MA): Cascadilla Proceedings Project, 2018. P. $341-348$.

Spronck, Nikitina 2019 - Spronck Stef, Nikitina Tatiana. Reported speech forms a dedicated syntactic domain // Linguistic Typology. 2019, 23 (1). P. 119-159. 